\title{
Understanding a New Method as Powerful Prevention of Noise-Induced Hearing Loss: Kurtosis Metric
}

\author{
Sunghwa You', Chanbeom Kwak², Saea Kim², Jangwon Lee², Seungyeop Jeong², \\ Eunsung Lee ${ }^{2}$, Hyunwook Song ${ }^{2}$, Nour Alsabbagh², Woojae Han ${ }^{1}$ \\ 'Division of Speech Pathology and Audiology, Research Institute of Audiology and Speech Pathology, College of Natural Sciences, \\ Hallym University, Chuncheon, Korea \\ ${ }^{2}$ Department of Speech Pathology and Audiology, Graduate School, Hallym University, Chuncheon, Korea
}

\section{소음성 난청의 효율적인 예방을 위한 첨도 측정법의 이해}

\author{
유성화 ${ }^{1} \cdot$ 곽찬범 $^{2} \cdot$ 김세아 $^{2} \cdot$ 이장원 $^{2} \cdot$ 정승엽 $^{2} \cdot$ 이은성 $^{2} \cdot$ 송현욱 $^{2} \cdot$ Nour Alsabbagh $^{2} \cdot$ 한우재 $^{1}$ \\ 한림대학교 자연과학대학 언어청각학부 · 청각언어연구소 ${ }^{1}$, 한림대학교 일반대학원 언어병리청각학과 ${ }^{2}$
}

\begin{abstract}
Purpose: In general, energy metrics, i.e., LAeq 8 hours, have been applied as a risk indicator of noise exposure. However, there are some limitations of LAeq measurement since it considers only the amount of average energy of noise and is not appropriate for measuring the complex noise. In light of this, the kurtosis metrics have been introduced by many contemporary researchers to be applied as an alternative measure. Methods: In the main body, we introduced the weakness of current noise exposure criteria, compared between Gaussian and non-Gaussian noise, briefly explained the concepts of kurtosis metrics, and scrutinized more applications of the kurtosis metrics by summarizing previous 7 research papers. Results: Compare to the Gaussian noise, the non-Gaussian noise has been found to have stronger cochlear damage effects on the outer and inner hair cells and led to permanent hearing loss in the higher frequencies. Noise exposure trauma levels were dramatically increased as the kurtosis levels increased. Although kurtosis metrics are a good indicator or measure, it still need to be adjusted in terms of frequency-specificity. Conclusion: Since the kurtosis metrics are not implemented in Korea, especially in the industrial field, we need to develop a new measurement approach using the kurtosis metrics on workers and then provide scientific based criteria for effectively preventing their potential risk of developing noise-induced hearing loss.
\end{abstract}

Key Words: Kurtosis, Gaussian noise, Non-Gaussian noise, Complex noise, Noise-induced hearing loss.

Received: April 5, 2018 / Revised: May 28, 2018 / Accepted: May 29, 2018

Correspondence: Woojae Han, Division of Speech Pathology and Audiology, Research Institute of Audiology and Speech Pathology, College of Natural Science, Hallym University, 1 Hallym Daehakgil, Chuncheon 24252, Korea

Tel: +82-33-248-2216 / Fax: +82-33-256-3420 / E-mail: woojaehan@hallym.ac.kr

\section{INTRODUCTION}

소음성 난청은 직업으로 인해 발생하는 대표적인 10대 질병 중 하나이다. 전 세계적으로 700 1,000만 명의 근로자가 85 $\mathrm{dBA}$ 이상의 소음에 노출되고 있으며(Davis et al., 2009), 이는 국제표준화기구(International Standard Organization, ISO), 미 국직업안전위생국(Occupational Safety and Health Association, OSHA), 미국국립표준기구(American National Standard Institute), 미국국립직업안전위생연구소(National Institute for
Occupational Safety and Health, NIOSH)에서 지정한 소음 노출의 위험 기준을 넘어서는 수준이다. 현재 전 세계적으로 통 용되는 소음 노출의 위험 기준은 노출 소음의 정도를 에너지 미 터법에 근거해서 산정하고 있다. 미국의 경우, 노동부에서 제정 한 Walsh-Healey ACT에 따르면 8시간 측정평균(LAeq 8 h)에 근거하여 $90 \mathrm{dBA}$ 까지 소음의 노출을 허용하고 있다. 유럽에서 는 노출된 소음의 총 에너지를 기반으로 한 동등에너지가설 (Equal Energy Hypothesis, EEH)에 따라 $85 \mathrm{dBA}$ 의 소음 강 도에서 $3 \mathrm{~dB}$ 씩 강도가 증가할수록 8시간의 허용시간을 $50 \%$ 씩 
줄이는 $3 \mathrm{~dB}$ 교환율(exchange rate)을 소음 노출의 기준으로 규 정하고 있다. 한편, 국내에서는 미국과 동일하게 $90 \mathrm{dBA}$ 의 소음 강도에서 $5 \mathrm{~dB}$ 씩 강도가 증가할수록 8시간의 허용시간을 반으 로 줄이는 $5 \mathrm{~dB}$ 교환율을 소음 노출의 기준으로 준수하고 있다.

이러한 에너지 미터법에 근거하여 8시간 동안 노출된 소음 강도의 평균적 측정은 소음의 특성이 지속적인 가우시안 소음 (Gaussian noise)일 경우 소음성 난청을 예방하는 기준으로 적 합하다. 하지만 충격음과 함께 결합되어 제시되는 복합 소음인 비가우시안 소음(non-Gaussian noise or complex noise)에는 적합하지 않다. 즉, 비가우시안 소음을 에너지 미터법에 근거하 여 측정할 경우 다양한 주파수적 특성을 구체적으로 반영하지 못하며 평균적 에너지 양(평균 강도)만 고려하는 한계를 갖는 다. 따라서 현재의 소음성 난청 예방 기준인 에너지 미터법의 적용은 최근 다수의 연구자에 의해 소음성 난청의 효과적인 예 방 및 효율적인 청력 보존의 관점에서 적절치 못하다고 주장되 었고(Canlon et al., 1988; Davis et al., 2009; Hamernik \& Ahroon, 1998; Zhao et al., 2010), 그 해결 방안으로써 첨도 측 정법이 제시되었다(Davis et al., 2009; Hamernik et al., 2003; Zhao et al., 2010). 소음의 강도와 시간적 특성을 민감하게 반영 하는 통계적 미터법인 첨도 측정법은 복합 소음의 노출과 이로 인한 유모세포 손상의 높은 상관성을 제시하기 때문에 소음 노 출 허용 기준을 제시할 때 평균 에너지 미터법인 LAeq와 함께 첨도 측정법을 적용하는 것이 매우 바람직하다(Davis et al., 2009; Zhao et al., 2010). 이에 본 종설에서는 현재 적용되고 있 는 소음노출기준의 한계점을 언급하고, 가우시안과 비가우시안 소음의 차이점, 첨도 측정법의 기본적 이해, 소음 노출에 대한 첨 도 측정법의 적용 연구 등에 관하여 기술하고자 한다. 또한, 향 후 연구 방향에 대한 첨도 측정법의 긍정적인 적용을 제안한다.

\section{WEAKNESS OF CURRENT NOISE EXPOSURE CRITERIA}

소음 노출로부터 근로자의 청력 손상을 평가 및 보호하기 위 해 equivalent sound levels, peak pressure levels, noise exposure rating 등과 같은 다양한 소음 측정 방법이 제시되어 왔고, 매개 변수에 대한 허용 수준은 국제표준화기구(ISO), 미국직업 안전위생국(OSHA), 미국국립직업안전위생연구소(NIOSH) 등 에서 공통적으로 제안하는 기준이 통용되고 있다(AlIdrisi et al., 1990). 그러나 미국직업안전위생국의 직업적 소음노출기준 (OSHA, 2014)은 8시간 가중 평균, 허용 소음 노출을 $90 \mathrm{dBA}$ 와 $5 \mathrm{~dB}$ 교환율로 규정하는 반면, 미국국립직업안전위생연구소 (NIOSH, 1998)는 8시간 가중 평균의 허용 소음 노출을 85 $\mathrm{dBA}$ 와 $3 \mathrm{~dB}$ 교환율로 권고하는 등 각 기구별로도 그 시작 기
준과 교환율에서 획일적이지 않다. 차이점을 좀 더 면밀히 살펴 보면, 미국직업안전위생국의 $5 \mathrm{~dB}$ 교환율은 8시간의 근무 조건 에서 지속적인 소음 노출 동안 여러 번의 간헐적인 소음 노출 의 중단 시(예를 들어, 근로자의 휴식 시간) 근로자의 일시적 역 치 변동(Temporary Threshold Shift, TTS) 중 일정 부분이 회 복될 수 있음을 가정하고 있다(Sriwattanatamma \& Breysse, 2000). 이에 반해, 미국국립직업안전위생연구소의 $85 \mathrm{dBA}$ 의 3 $\mathrm{dB}$ 교환율 적용은 동등에너지가설(EEH)에 근거하여 음향 에너 지의 분포와 관계없이 동등한 양의 음향 에너지는 그에 상응하 는 청력 손실을 유발함을 내포하고 있다(Suter, 1992). 다시 말해 동등에너지가설은 잠재적인 소음성 외상이 노출의 총 $\mathrm{A}$-가중 데시벨(에너지 $=$ 힘 $\times$ 시간)과 직접적으로 관련된다고 강조하 고 있다(Eldred, 1976; Ward et al., 1961).

2000년대에 들어와서는 Hamernik \& Qiu(2001), Harding \& Bohne(2004), Qiu et al.(2006), Hamernik et al.(2007)에 의 해 새로운 연구 결과가 제시되면서 기존의 동등에너지가설에 근거한 청력 보존 전략은 궁극적으로 근로자의 소음성 난청 예 방에 적절하지 않다는 의견이 제기되었다. 즉, 그들의 연구 결 과에서는 공통적으로 단위 시간당 동등한 에너지를 가진 지속 적인 소음, 규칙적 혹은 불규칙적 충격음, 지속적인 소음과 충 격음이 결합된 복합 소음 등 소음의 각기 다른 유형과 특징에 따라 청력 손실의 정도가 다르게 나타날 수 있음이 증명되었고, 기존의 소음 강도와 노출 시간 사이의 상충 관계를 기반으로 한 에너지 미터법과 비교하여 보다 자세하고 과학적인 기준을 세우는 데 근거로써 주장되었다(Davis et al., 2009).

\section{GAUSSIAN AND NON-GAUSSIAN NOISE}

가우시안 소음이란 충격음 없이 거의 일정한 스펙트럼을 나 타내는 지속적인 소음(steady-state noise)을 뜻한다(Hamernik et al., 2003). 대표적인 예로 백색소음(white noise)이 있으며, 일을 할 때 근로자에게 지속적으로 노출되는 베틀 소리, 보일 러 소리, 에어컨 소리, 환기 소리 등이 있다. 따라서 특성상 일반 적이면서도 사람들의 귀에 지속적인 강도로 제시되는 소음을 가우시안 소음이라고 정의된다. 반면, 복합 소음(complex noise) 또는 간헐적인 소음(intermittent noise)이라고도 불리는 비가우시안 소음은 일정한 강도를 지닌 지속적인 소음 내에 여 러 번의 간헐적인 충격음이 함께 결합되어 제시된다. 예를 들 어, 펀치프레스업(95.3 dBA), 직물업(105 dBA), 금속가공업(95 $\mathrm{dBA}$ ) 등에서 종사하는 근로자는 지속적인 소음이 제시되는 환경 내에서 지속적인 소음의 강도보다 큰 간헐적인 충격음에 노 출되고 있다. 비가우시안 소음 내에 지속적인 소음과 간헐적인 고강도 충격음의 차이는 약 20 30 dB 정도 상이할 수 있으며, 충 
격음의 결합방식 혹은 패턴에 따라 청력 손상의 정도 및 양상이 달라질 수 있다(Suter, 2017). 다시 말해, 지속적인 소음과 충격음 을 모두 포함한 비가우시안 소음은 지속적인 소음과 충격음이 각 각 제시될 때보다 훨씬 큰 시너지 효과를 나타낸다(Hamernik et al., 2003).

Figure 1을 통해, 4가지 비가우시안 소음의 특징을 나타내는 예를 제시하였다. Figure 1 의 $\mathrm{A}$ 와 $\mathrm{B}$ 는 동일한 시간 동안 제시 된 비가우시안 소음으로서, Figure $1 \mathrm{~A}$ 에 나타난 두 가지 비가 우시안 소음은 간헐적인 충격음이라는 공통점은 있지만 제시 된 충격음의 길이에는 차이가 있다. Figure $1 \mathrm{~B}$ 의 비가우시안 소음은 Figure $1 \mathrm{~A}$ 에서 나타난 소음과 다르게 충격음의 강도 크기가 시간에 따라 변화하며, 두 가지 소음 역시 각각 제시된 충격음의 길이가 다르다(Passchier-Vermeer, 1973). 만일, 에너 지 미터법에 따라 단위시간 내 소음의 강도를 측정한다면, 평균 적 에너지만을 고려하기 때문에 패널 $\mathrm{A}$ 와 $\mathrm{B}$ 에 제시된 다른 두 가지 소음은 충격음의 길이에 관계없이 같은 강도의 소음으로 측정되어 소음성 난청 예방 기준에 적용될 수 있다. 따라서, 비 가우시안 내에서 각기 다른 충격음의 특성을 보다 잘 반영하기
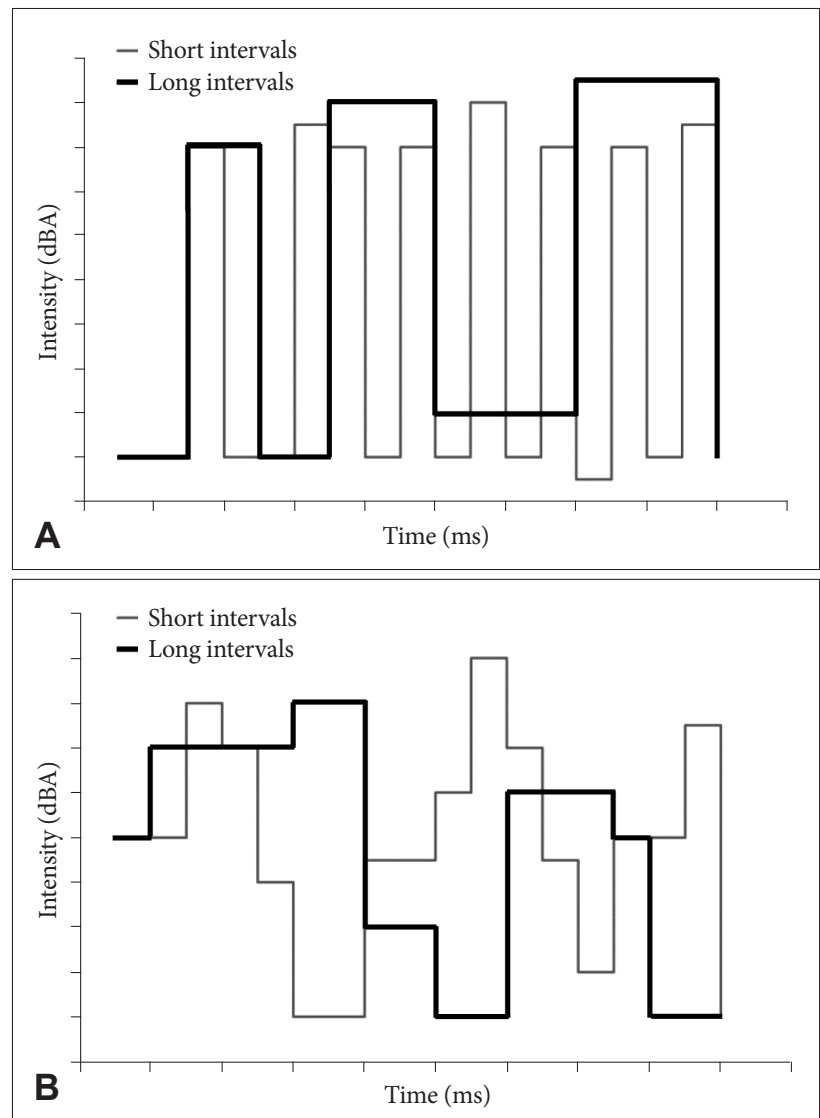

Figure 1. Graphical example of the short-interval and long interval non-Gaussian noise. A: Comparison of short-interval and long-interval noise for intermittent noise exposure. B: Comparison of short-interval and long-interval noise for varying noise exposure.
위한 측정 방법이 필요하다.

\section{CONCEPT OF KURTOSIS METRICS}

Erdreich(1986)는 강한 환경 소음을 보다 정교하게 수치화하 기 위해 노출된 소음의 형태가 평균에 얼마나 집중되어 있는지 (peakedness)와 얼마나 넓게 분포하고 있는지(tailedness)를 반 영하는 인자로서 첨도(kurtosis)를 제시하였다. 통계학적으로 1차 적률(1st moment)은 평균(mean), 2차 적률(2nd moment)은 분 산(variance)이라고 표현한다. 또한, 3차 적률(3rd moment)은 왜도(skewness), 4차 적률(4th moment)은 첨도를 정의하는 데 사용한다. 첨도는 4 차 적률을 분산의 제곱으로 나눈 값이며, 확률 분포의 뽀족한 정도를 나타내는 수치이다. 계산 과정에서 측정된 모든 소음의 양을 각각 표준값으로 전환하고 표준값은 측정값에 4 배를 한 후 측정치의 수로 나누어 $\beta$ 값을 얻는다 (Figure 2의 왼쪽 패널 수식 참조). 시각적 이해를 돕기 위해 Figure 2의 오른쪽 패널에 3가지 크기의 첨도를 제시하였다. 첨 도는 $\beta$ 값을 통해 도수 분포가 얼마나 뾰족한지 혹은 얼마나 평 평한지를 나타내는 척도이므로, 얻어진 $\beta$ 값이 0 보다 크지만 3 보다 작으면 분포는 완첨(platykurtic, 평평함), 3과 같으면 중첨 (mesokurtic, 높이가 정상적임), 3보다 크면 급첨(leptokurtic, 뾰 족함)이라 한다.

일정 시간 동안 소리의 압력 대 시간 파형을 분석하였을 때, 충격음이 포함된 비가우시안 소음의 경우 가우시안 소음보다 높은 진폭의 분포(variable $\mathrm{x})$ 로 인해 급첨 $(\beta>3)$ 으로 나타난 다. 따라서, 급첨 $(\beta>3)$ 을 나타내는 비가우시안 소음은 가우시 안 소음의 노출에 비해 청력 손실에 유해한 요소가 된다.

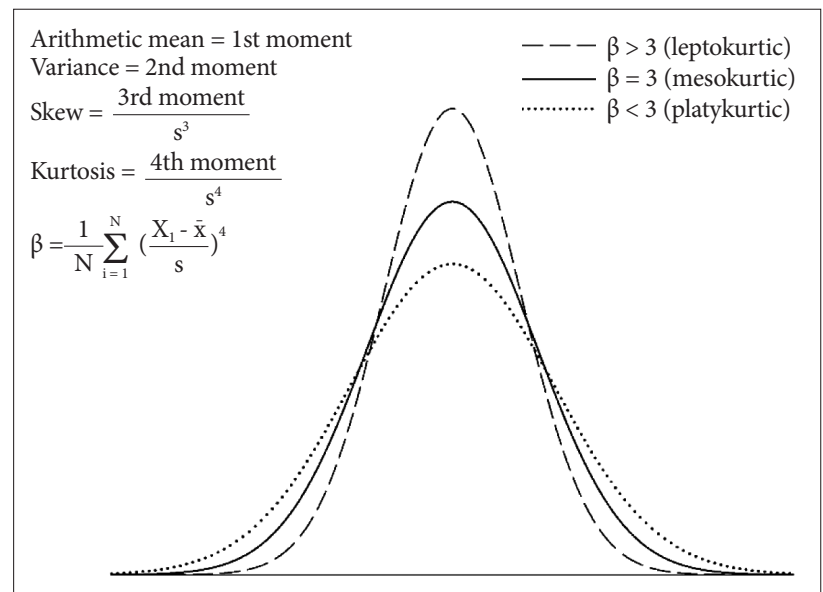

Figure 2. Left panel: The variable $x$ is amplitudes of the pressuretime waveform at discrete points over some periods of time. The Nth order moment is defined as the average of $\left(X_{1}-C\right)^{n}$, where the $C$ is a constant. In the presented formulas, also represents the standard deviation and $\bar{x}$ represent the expected value. Right panel: Instruction of the descriptive statistical display for distributions of the variable $x$. 


\section{APPLICATION OF KURTOSIS METRIC FOR NOISE EXPOSURE STUDY}

많은 선행연구들은 비가우시안 소음 노출 시 청력 손실의 정 도와 유병률을 효과적으로 예측하기 위한 측정법으로 첨도를 사용하였다. Lei et al.(1994)의 연구에서는 44마리의 친칠라를 3 가지 소음으로 나누어 가우시안 소음, 폭발음 $(106 \mathrm{~dB}$ peak $\mathrm{SPL})$ 이 결합된 비가우시안 소음, 충격음 $(125 \mathrm{~dB}$ peak SPL)이 결합된 비가우시안 소음에 5일 동안 지속적으로 노출시켰다. 실험에 사용된 3가지의 소음은 모두 동일한 에너지와 스펙트럼 을 지녔지만 첨도값만 다르게 적용하였다. 예를 들어, 가우시안 소음의 첨도값( $\beta$ )은 3 , 폭발음과 결합된 비가우시안 소음의 첨 도값은 21 , 충격음과 결합된 비가우시안 소음의 첨도값은 84였 다. Figure 3을 통해, 각각의 소음에 노출된 세 그룹의 모세포 손실 정도(Figure $3 \mathrm{~A}-\mathrm{C}$ )와 영구적 역치 변동(TTS) (Figure $3 \mathrm{D})$ 을 제시하였다. 구체적으로 첨도값이 $\beta=3,21,84$ 의 소음 을 비교했을 때, 노출된 소음의 첨도값이 클수록 유모세포의 잠재적 손상은 극적인 상승이 나타났고 고주파수에서 보다 많 은 양의 유모세포 손실이 나타났다. 일반적으로 외유모세포의 손상이 두드러지지만, $\beta=84$ 의 첨도값을 지닌 비가우시안 소
음에 노출된 후에 내유모세포의 손실은 중·저주파수까지 확장 된다(Figure $3 C$ ). 또한 비가우시안 소음 $(\beta=84)$ 에 노출 시 가우 시안 소음 $(\beta=3)$ 보다 약 $40 \mathrm{~dB} \mathrm{HL}$ 의 영구적 청력 손실 차이가 나타난다(Figure $3 \mathrm{D})$. 이에 근거하여, $\mathrm{LAeq}$ 측정법을 이용하여 소음을 측정한다면, 유모세포 손상의 차이 및 소음 노출 정도, 청력 손실의 상관관계를 확인할 수 없다.

Dunn et al.(1991)의 연구에서는 16마리의 친칠라를 두 그룹 으로 나누어 각각 가우시안 소음(pink noise), 비가우시안 소음 (충격음)에 노출시켰다. 5일 동안 하루 4시간씩 소음에 노출시 켰으며, 30 일 이후 청력 역치를 측정한 결과, 예상한 대로 비가우 시안 소음 그룹의 청력 역치 변동은 가우시안 소음에 노출된 그 룹의 청력 역치 변동보다 유의미하게 더 크게 나타났다. Lataye \& Campo(1996)의 연구 또한, 29마리의 기니피그 두 그룹을 대 상으로 진행하여 $\mathrm{LAeq}$ 의 적용 적합성을 확인하기 위하여 동 일한 음향 스펙트럼을 갖는 가우시안 소음과 비가우시안 소음 을 비교하였다. 저자들은 LAeq의 소음 측정법 적용은 정확한 손상위험기준(damage-risk criterion)이 아님을 보고하였고, 가 우시안 소음과 비가우시안 소음 모두 적용할 수 있는 청력 손 실 예방 측정법이 새로이 제안되어야 한다고 결론 지었다. 제시 된 3가지 동물 연구의 결과를 종합해 보면, 비가우시안 소음의
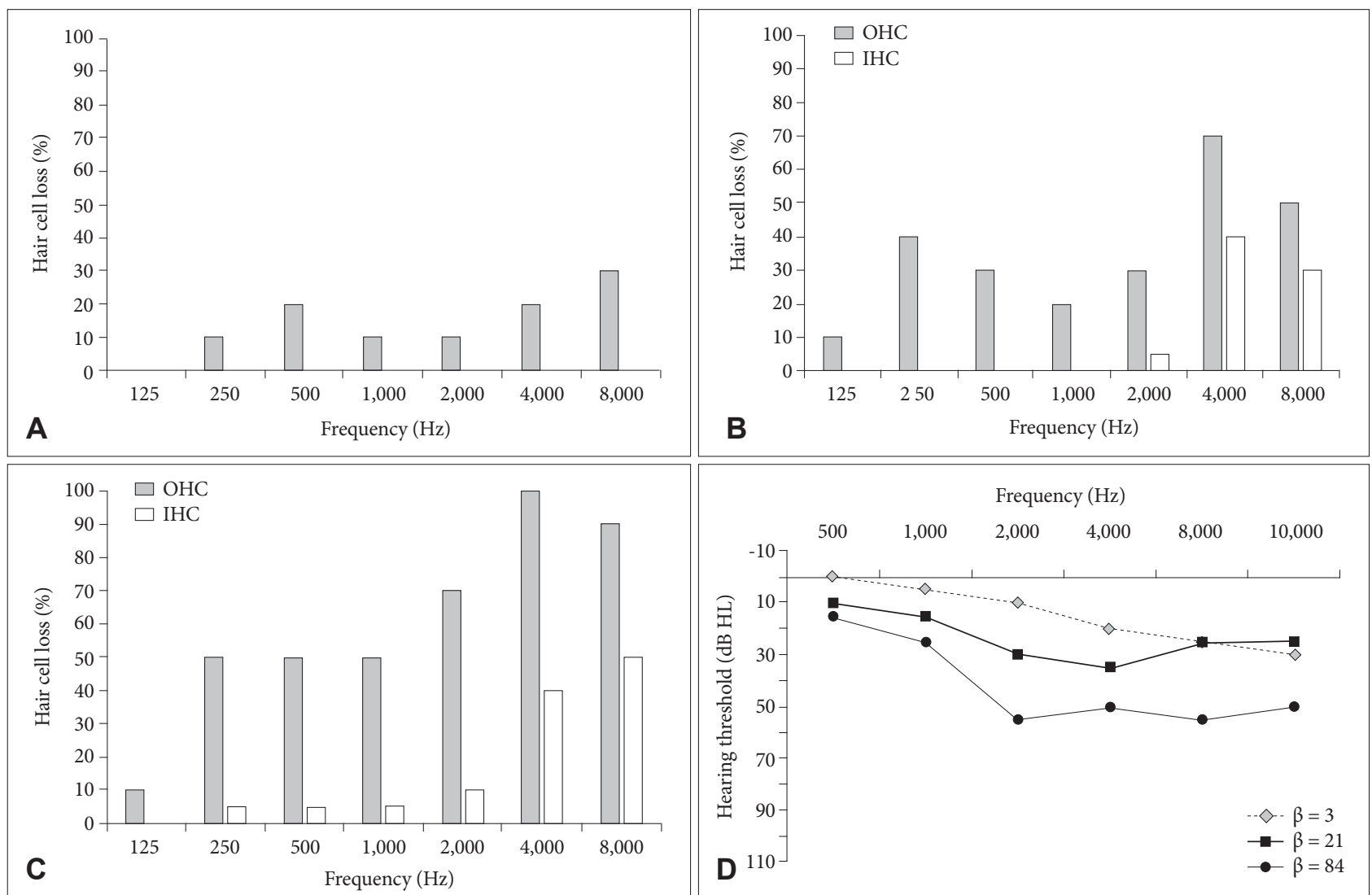

Figure 3. Damage percentage of outer and inner hair cell loss based on different beta values, i.e., $\beta=3(A), \beta=21$ (B), $\beta=84$ (C), and its potential pure-tone audiometric results. It is a graphical display inferred from data of Lei et al. (1994). OHC: outer hair cell, IHC: inner hair cell. 
노출로 인한 청력 손실은 동등한 에너지 분포를 가진 가우시안 소음의 노출로 인한 청력 손실과 비교했을 때 더욱 두드러지게 나타났다(Dunn et al., 1991; Lataye \& Campo, 1996; Lei et al., 1994).

Zhao et al.(2010)의 연구에서는 두 산업 공장에 종사하는 근 로자의 청력 손실의 유병률을 비교하였다. 공장 $\mathrm{A}$ 는 8 시간 평 균 95 105 $\mathrm{dBA}$ 의 가우시안 소음을 가진 섬유업이었고, 공장 $\mathrm{B}$ 는 8 시간 평균 $95 \mathrm{dBA}$ 의 소음과 $125 \mathrm{~dB}$ peak SPL의 충격 음이 결합된 비가우시안 소음을 갖는 금속 가공업이었다. 두 공장에서 발생하는 소음을 첨도 측정법으로 계산한 결과, 공장 $\mathrm{A}$ 의 첨도값 $(\beta)$ 은 3.3 , 공장 $\mathrm{B}$ 의 첨도값( $\beta$ )은 40 이었다. 공장 $\mathrm{A}$ (가우시안 소음)와 공장 $\mathrm{B}$ (비가우시안 소음)의 각 소음을 축 적 소음(cumulate noise exposure, $\mathrm{CNE}^{1}$ )으로 로지스틱 회귀 (Logistic Regression) 모델에 적용시켰다. 가우시안 소음에 노 출된 공장 $\mathrm{A}$ 의 평균 축적 소음값은 $110.6 \pm 6.0 \mathrm{~dB}$, 비가우시 안 소음에 노출된 공장 $\mathrm{B}$ 의 평균 축적 소음값은 $103.2 \pm 4.2$ $\mathrm{dB}$ 로 공장 $\mathrm{A}$ 의 평균 축적 소음값이 $7 \mathrm{~dB}$ 더 높았다. 그러나 공장 $\mathrm{A}$ 의 평균 소음 수준이 더 높음에도 불구하고 $2,4,6,8$ $\mathrm{kHz}$ 에서 청력 손실 $(\geq 30 \mathrm{~dB} \mathrm{HL})$ 이 발생되는 유병률은 두 공 장의 근로자에게서 동일하게 나타났고, 오히려 공장 $\mathrm{B}$ 의 근로자 는 공장 $\mathrm{A}$ 의 근로자에 비해 근무 연수가 높아질수록 더 빠르게 청력 손실의 유병률이 높아졌다. 다시 말해, 공장 $\mathrm{B}$ 의 근로자는 공장 $\mathrm{A}$ 의 근로자와 비교하여 평균 $7 \mathrm{~dB}$ 정도 낮은 축적 소음을 가졌지만, 해를 거듭하면서 잠재적인 청력 손실의 발생 가능성 은 더 높게 분석되었고, 비가우시안 소음에 노출된 근로자는 가 우시안 소음에 노출된 근로자보다 고주파수 난청이 발생할 확 률이 $40.9 \%$ 더 높다고 예측되었다. 이러한 결과는 앞선 동물 실 험의 연구 결과와 유사하였고, 비가우시안 소음 노출은 지속적 인 에너지 등가를 갖는 가우시안 소음에 노출된 경우보다 청력 손실에 더 위험함을 다시 한 번 강조한다(Davis et al., 2009; Hamernik et al., 2003; Qiu et al., 2006, 2007).

종합해 보면, 첨도( $\beta$ )는 정점(peak)과 시간(temporal)에 민감 한 통계적 특성을 가지며 이를 통해 비가우시안 소음 노출로 인한 잠재적 청력 손실을 보다 민감하게 탐지할 수 있다(Davis et al., 2009; Hamernik et al., 2003; Qiu et al., 2006, 2007). 고정된 동등 에너지 수준에서 첨도가 증가함에 따라 소음으로 인한 청력 손실이 증가한다는 것을 보여주었고, 이는 LAeq 측 정법과 결합된 첨도 측정법이 청력 보존의 목적을 위한 소음 평가에 유용하게 적용될 수 있는 가능성을 시사한다.

Table 1에서는 첨도 측정법을 적용한 7개의 선행연구들을 분 석하여 정리하였다. 근로자를 대상으로 연구한 Zhao et al. (2010)의 논문을 제외하고는 대부분의 논문에서 친칠라를 대 ${ }^{1} \mathrm{CNE}=\mathrm{LAeq} 8 \mathrm{~h}+10 \log \mathrm{T}$ (where $\mathrm{T}$ is exposure time in years).
상으로 가우시안 소음과 비가우시안 소음의 제시 강도를 여러 단계로 달리하면서 일정 시간의 소음 노출 후 변화된 청력 역 치를 측정하였다. 7 개의 논문에서 공통적으로 소음 노출로 인 한 정확한 청력 손실을 측정하는데 소음의 특성을 고려한 첨 도 측정법이 효과적인 방법이라고 보고하였다. 또한, $90 \mathrm{dBA}$ 이상의 가우시안 소음과 $\beta>3$ 의 충격음이 결합된 비가우시안 소음에 노출될 경우, 산업체 근로자의 모세포 손실에 크게 유 해할 수 있음을 결론 지었다.

\section{CONSIDERATION OF KURTOSIS METRIC}

정리해 보면, 비가우시안 소음으로 인한 청력 손상을 효과적 으로 측정하기 위해 첨도 측정법을 적용해야 하고 중요한 변수 로서 첨도값과의 연관성을 이해하는 것은 매우 중요하다. 그러 나 첨도 측정법의 적용이 비가우시안 소음을 측정하는 데 가 장 우수한지는 아직 고려해야 할 점도 분명 존재한다. Qui et al.(2006)은 106마리의 친칠라에게 90 110 dBA의 가우시안 소 음에 첨도값을 달리하며 노출시켰을 때, $90 \mathrm{dBA}$ 의 LAeq에 노 출된 그룹은 첨도값의 변화에 관계없이 동일한 정도의 청력 손 상을 보였지만, $90 \mathrm{dBA}$ 보다 높은 강도의 소음에선 비가우시안 소음에 노출된 친칠라에게서 더 큰 청력 손상이 나타났다. Harding \& Barbara(2004)의 연구 또한 416마리의 친칠라에게 $500 \mathrm{~Hz}$ 와 $4 \mathrm{kHz}$ 의 옥타브 밴드의 소음을 사용하였고, $4 \mathrm{kHz}$ 에서는 86 90 dBA, $500 \mathrm{~Hz}$ 에서는 $95 \mathrm{dBA}$ 보다 높은 강도의 소음에 노출되었을 때 LAeq에 의해 예측된 것보다 많은 청력 손실이 발견되어 주파수에 따라 첨도에서 고려해야 할 부분이 있음을 시사하였다. 즉, $\mathrm{LAeq} \leq 90 \mathrm{dBA}$ 의 소음 측정에 있어 서는 기존 LAeq 측정법인 동등에너지가설을 적용할 수 있으 나, $90 \mathrm{dBA}$ 보다 높은 고강도의 소음을 측정 시 기존의 소음 측정방법은 소음 노출 및 그 손상을 과소평가할 수 있기 때문 에 첨도가 적용된 소음 측정이 필요하다.

한편 Zhu et al.(2009)은 복합 소음의 위험성을 평가하기 위한 수단으로써 첨도를 포함한 14가지의 소음 측정 지표(noise metric)를 적용하고 실험하였다. 친칠라를 대상으로 평균 $100 \mathrm{~dB}$ $\mathrm{SPL}$ 의 다양한 특성의 소음들과 여러 수준의 첨도를 적용하여 제시한 후 각 소음의 측정 지표와의 상관성을 비교 분석한 결 과, 첨도는 주파수 상관성(frequency correlation), 소음 상관성 (noise correlation), 전반적 상관성(overall correlation)의 3가 지 모든 측면을 고려하여 분석하기에는 강력한 측정법은 아니 라고 주장하였다. 그러나 Zhu et al.(2009)의 결과는 실제 산업 환경의 근로자가 노출되는 복합 소음이 아닌 실험실에서 인위 적으로 조작된 소음이기 때문에 산업 현장의 실제 소음을 적용 하여 3 가지 상관성을 다시 분석할 필요가 있다. 더불어 비가우 


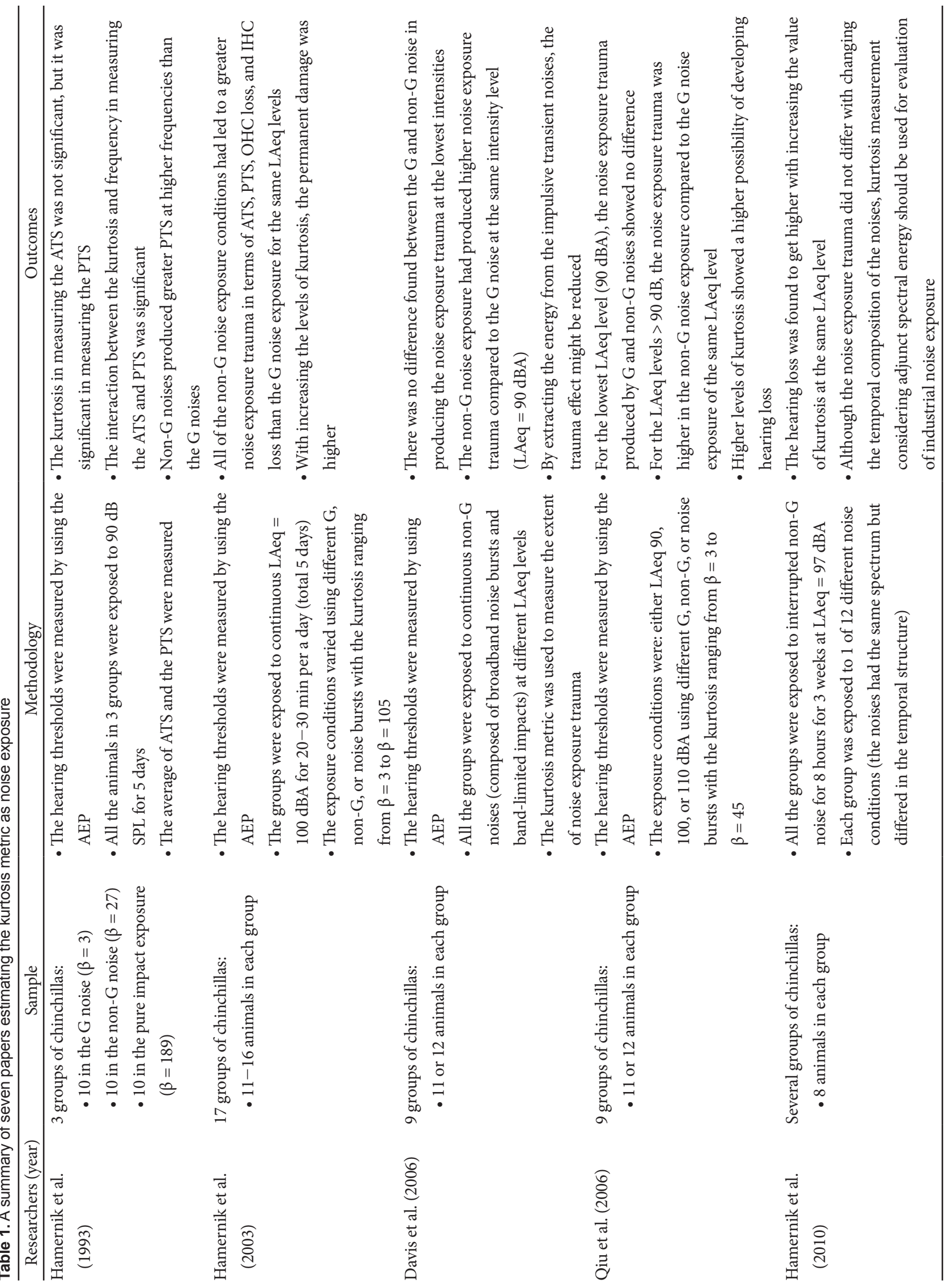




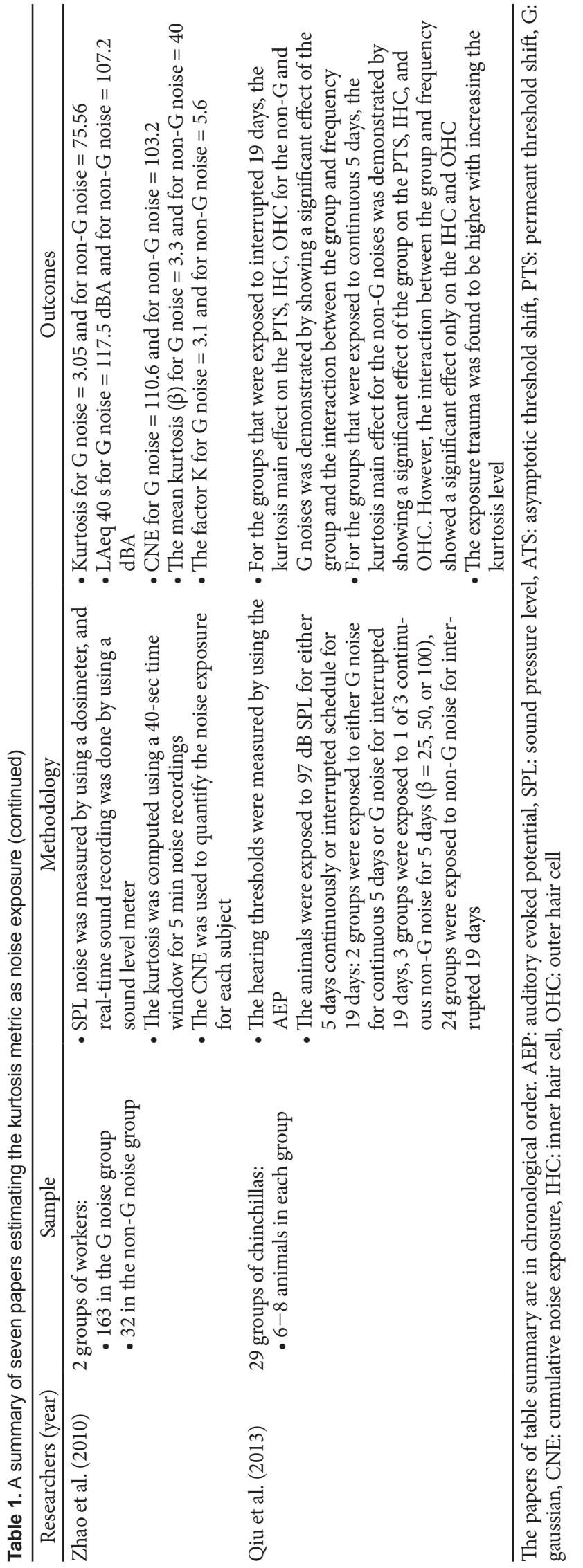

시안 소음은 충격음의 경우 적어도 $90 \mathrm{dBA}$ 이상의 소리가 대 부분이므로 첨도의 사용을 우선적으로 고려하는 것이 중요하 며, 첨도 이용 시 자극의 상대적인 정점들(relative peaks)과 충 격음의 지속 시간, 신호의 반복 주기를 반영함으로써 노출 자 극의 시간적, 강도적 특성을 가져 간헐적인 소음의 측정에 있어 유리하다는 장점이 있다(Erdreich, 1986; Hamernik \& Qui, 2001). 따라서 구체적인 첨도 적용 연구를 수행하여 현재의 첨 도 측정법을 보완할 필요가 있다.

\section{CONCLUSIONS}

산업안전보건공단의 보고에 따르면 소음성 난청은 2016년 국내 산업 근로자의 건강진단 결과 가장 많이 발생한 직업병이 며, 소음성 난청 유소견자(D1)는 2000년 1,368명에서 2016년 11,456 명으로 8.47배 높아졌고, 전년 대비 1,414 건(14.1\%)의 증가 추세를 보였다(KOSHA, 2016) (Figure 4). 앞서 언급한 대로, 현 재 국내의 소음 노출 적용 기준은 미국직업안전위생국(OSHA) 에 근거하여 $90 \mathrm{dBA}$ 의 최대 8시간 노출로 규정한다. 소음 노출 기준보다 $5 \mathrm{~dB}$ 씩 높을수록 근로시간이 $50 \%$ 씩 감소하는 $5 \mathrm{~dB}$ 교환율 법칙이 적용되며, 최대 작업장 소음 노출은 $115 \mathrm{dBA}$ 이다. 국내의 관련 문헌들을 살펴보면, 국내 22,384개의 사업장을 대상으로 2001년도에 실시한 작업환경 소음노출평가 결과에서 Roh \& Phee(2003)는 총 5,785개의 업체가 $90 \mathrm{dBA}$ 기준을 초 과하는 사업장으로 분류하였고, 2002 2005년 동안 실시한 Jang \& Chung(2007)의 연구에서는 3 4만 개 사업장의 작업 환경에서 소음을 측정한 결과 전체 사업장의 $90 \%$ 이상이 1 일 8시간 작업기준 $90 \mathrm{dBA}$ 소음노출기준을 초과하였다. 앞서 언 급했듯이 이러한 측정 결과는 8시간 평균인 LAeq의 $90 \mathrm{dBA}$ 강도 기준을 적용한 분석이기 때문에 본 종설에서 설명한 소음 의 특성과 비가우시안 소음의 패턴을 측정하는 데 첨도 측정법 을 적용하지 못하였다. 이러한 결과 분석은 산업 근로자의 축 적 소음에 따른 잠재적 청력 손실을 예측하기에는 매우 큰 한 계가 있다고 단언할 수 있다.

본 종설에서는 가우시안 소음과 비가우시안 소음의 차이를 설명하면서 비가우시안 소음 측정에 적합한 첨도 측정법을 소 개하였다. 많은 선행연구들에서는 가우시안 소음과 비교 시, 비 가우시간 소음에 따른 보다 큰 청력 손실의 정도에 대해 위험 성을 경고하고 있다. 즉, 동일한 강도로 지속되는 가우시안 소 음에 비해 동일한 강도의 소음과 더불어 간헐적인 충격음이 혼 합되어 나타나는 비가우시안 소음의 노출로 인한 청력 손실의 위험성은 더 치명적이다. 따라서 기존에 획일적으로 사용되던 소음 노출의 평균 강도와 시간을 적용한 에너지 미터법의 한계 점에 첨도 측정법을 적용한다면 보다 과학적인 예방법을 제시 


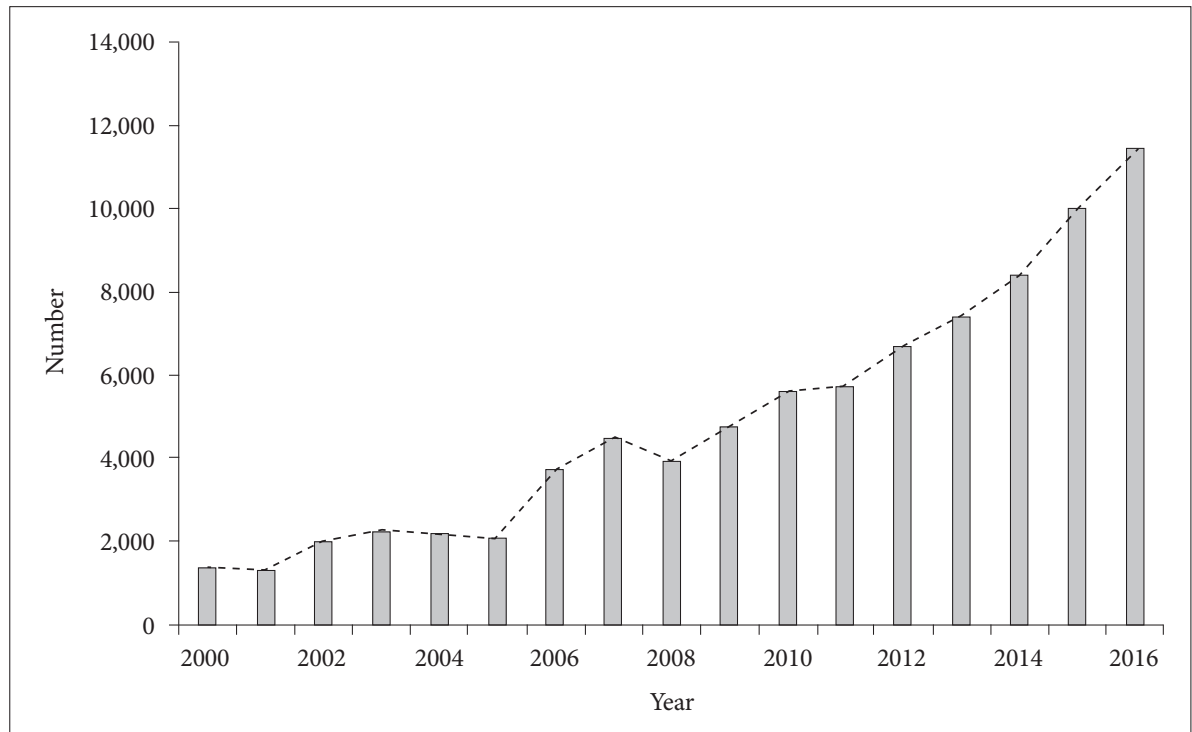

Figure 4. Number of workers and its tendency with suspicious noise-induced hearing loss from 2000 to 2016 in South Korea (data extracted from KOSHA, 2016).
할 수 있을 것으로 기대한다.

전 세계적으로, 대략 1,000 만 명에 가까운 많은 수의 산업체 근로자가 $85 \mathrm{dBA}$ 이상의 고강도 소음에 노출되고 있기 때문에 (Davis et al., 2009), 노출 소음의 복합적 특성 및 시너지적 위 험성에 대한 심도 있는 이해와 이를 통한 철저한 대처가 필요하 다. 또한, 산업체 근로자뿐만 아니라 복합 소음의 일종인 유희 적 소음에 노출되는 일반 대중의 소음성 난청의 예방 및 청력 보존의 관점에서 보다 정밀한 소음 노출 수준의 측정과 예방 기준이 매우 시급하다. 거리의 소음에 노출되면서 휴대용 음향 기기를 통한 고강도의 음악 청취, 스포츠 관람 시 발생하는 경 기 소음 및 응원 소음에의 노출, 군부대에서의 훈련 시 사용되 는 다양한 총기류의 소음 등 두 가지 이상의 소음이 복합되어 발생하는 복합적 유희적 소음의 비가우시안적 분석과 해석이 명확히 제시되어야 하겠다. 이를 위해 청각 전문가는 노출되는 소음의 특성을 고려한 정확한 측정법의 사용은 물론 효율적인 소음성 난청의 예방과 보존을 위해 보다 분별 있는 소음 측정 을 고려해야 할 것이다.

\section{중심 단어 : 첨도 측정법·가우시안 소음·비가우시안 소음· 복합 소음·소음성 난청.}

\section{Ethical Statement \\ N/A}

\section{Acknowledgments \\ N/A}

\section{Declaration of Conflicting Interests}

There are no conflict interests.

\section{Funding}

This research was completed while being supported by National Re- search Foundation of Korea (NRF-2017R1A1A1A05001299).

\section{REFERENCES}

AlIdrisi, M., Jamil, A. T. M., Al-Jiffry, M. S., Jefri, M. A., \& Erturk, F. (1990). Evaluation of noise stresses in Jeddah industrial estate. Journal of Environmental Science and Health. Part A: Environmental Science and Engineering and Toxicology, 25(8), 873-896.

Canlon, B., Borg, E., \& Flock, A. (1988). Protection against noise trauma by pre-exposure to a low level acoustic stimulus. Hearing Research, 34(2), 197-200.

Davis, R. I., Qiu, W., \& Hamernik, R. P. (2006). Noise-induced hearing loss from non-Gaussian equal energy exposures. The Journal of the Acoustical Society of America, 120(5), 3128-3129.

Davis, R. I., Qiu, W., \& Hamernik, R. P. (2009). Role of the kurtosis statistic in evaluating complex noise exposures for the protection of hearing. Ear and Hearing, 30(5), 628-634.

Dunn, D. E., Davis, R. R., Merry, C. J., \& Franks, J. R. (1991). Hearing loss in the chinchilla from impact and continuous noise exposure. The Journal of the Acoustical Society of America, 90(4 Pt 1), 1979-1985.

Eldred, K. (1976). Demographics of noise pollution with respect to potential hearing loss. In Henderson, D., Hamernik, R. P., Dosanhj, D. S., \& Mills, J. Effects of Noise on Hearing. (pp. 3-20). New York, NY: Raven Press.

Erdreich, J. (1986). A distribution based definition of impulse noise. The Journal of the Acoustical Society of America, 79(4), 990-998.

Hamernik, R. P. \& Ahroon, W. A. (1998). Interrupted noise exposures: Threshold shift dynamics and permanent effects. The Journal of the Acoustical Society of America, 103(6), 3478-3488.

Hamernik, R. P., Ahroon, W. A., Hsueh, K. D., Lei, S. F., \& Davis, R. I. (1993). Audiometric and histological differences between the effects of continuous and impulsive noise exposures. The Journal of the Acoustical Society of America, 93(4 Pt 1), 2088-2095.

Hamernik, R. P. \& Qiu, W. (2001). Energy-independent factors influencing noise-induced hearing loss in the chinchilla model. The Journal of the Acoustical Society of America, 110(6), 3163-3168.

Hamernik, R. P., Qiu, W., \& Davis, B. (2003). The effects of the amplitude distribution of equal energy exposures on noise-induced hearing loss: The kurtosis metric. The Journal of the Acoustical Society of America, 114(1), 386-395.

Hamernik, R. P., Qiu, W., \& Davis, B. (2007). Hearing loss from interrupted, intermittent, and time varying non-Gaussian noise exposure: The applicability of the equal energy hypothesis. The Journal of the Acousti- 
cal Society of America, 122(4), 2245-2254.

Hamernik, R., Qiu, W., \& Davis, R. (2010). The use of the kurtosis metric in the evaluation of industrial noise exposures. The Journal of the Acoustical Society of America, 128(4), 2456.

Harding, G. W. \& Bohne, B. A. (2004). Noise-induced hair-cell loss and total exposure energy: Analysis of a large data set. The Journal of the Acoustical Society of America, 115(5 Pt 1), 2207-2220.

Jang, J. K. \& Chung, K. J. (2007). A Study on the Management of Noise in Work-Environments. Ulsan: Occupational Safety and Health Research Institute.

Lataye, R. \& Campo, P. (1996). Applicability of the L(eq) as a damage-risk criterion: An animal experiment. The Journal of the Acoustical Society of America, 99(3), 1621-1632.

Lei, S. F., Ahroon, W. A., \& Hamernik, R. P. (1994). The application of frequency and time domain kurtosis to the assessment of hazardous noise exposures. The Journal of the Acoustical Society of America, 96(3), 14351444.

Ministry of employment and labor. (2016, February). Workers' Health Examination Practices. Korea Occupational Safety and Health Agency. Retrieved from http://www.kosha.or.kr/.

Occupational Safety and Health Administration. (2014). Regulations (Standards-29 CFR)-Table f Contents. Washington, DC: US Department of Labor.

Passchier-Vermeer, W. (1973). Proceedings of the international congress on noise as a public health problem: Noise Induced Hearing Loss from Exposure to Intermittent and Varying Noise. (pp. 169-200). Washington, DC: U.S. Environmental Protection Agency.

Qiu, W., Davis, B., \& Hamernik, R. P. (2007). Hearing loss from interrupted, intermittent, and time varying Gaussian noise exposures: The applicability of the equal energy hypothesis. The Journal of the Acoustical Society of America, 121(3), 1613-1620.
Qiu, W., Hamernik, R. P., \& Davis, B. (2006). The kurtosis metric as an adjunct to energy in the prediction of trauma from continuous, nonGaussian noise exposures. The Journal of the Acoustical Society of America, 120(6), 3901-3906.

Qiu, W., Hamernik, R. P., \& Davis, R. I. (2013). The value of a kurtosis metric in estimating the hazard to hearing of complex industrial noise exposures. The Journal of the Acoustical Society of America, 133(5), 28562866.

Roh, Y. M. \& Phee, Y. G. (2003). Analysis of industry types exceeding noise exposure limit in Korea. Journal of Korean Society of Occupational and Environmental Hygiene, 13(1), 53-61.

Sriwattanatamma, P. \& Breysse, P. (2000). Comparison of NIOSH noise criteria and OSHA hearing conservation criteria. American Journal of Industrial Medicine, 37(4), 334-338.

Suter, A. H. (1992). The Relationship of the Exchange Rate to Noise-Induced Hearing Loss. Cincinnati, OH: Alice Suter and Assoc.

Suter, A. H. (2017). Occupational hearing loss from non-Gaussian noise. Seminars in Hearing, 38(3), 225-262.

U.S. Department of Health and Human Services. (1998, June). Criteria for a Recommended Standard. Centers for Disease Control and Prevention. Retrieved from https://www.cdc.gov/niosh/.

Ward, W. D., Fleer, R. E., \& Glorig, A. (1961). Characteristics of hearing losses produced by gunfire and by steady noise. Journal of Auditory Research, 1(5), 325-356.

Zhao, Y. M., Qiu, W., Zeng, L., Chen, S. S., Cheng, X. R., Davis, R. I., et al. (2010). Application of the kurtosis statistic to the evaluation of the risk of hearing loss in workers exposed to high-level complex noise. Ear and Hearing, 31(4), 527-532.

Zhu, X., Kim, J. H., Song, W. J., Murphy, W. J., \& Song, S. (2009). Development of a noise metric for assessment of exposure risk to complex noises. The Journal of the Acoustical Society of America, 126(2), 703-712. 